\title{
Urban metabolism using economic input-output analysis for the city of Barcelona
}

\author{
F. A. Shafie ${ }^{1,3}$, D. Omar ${ }^{1}$, S. Karupannan ${ }^{2}$ \& X. Gabarrell ${ }^{3}$ \\ ${ }^{1}$ Faculty of Architecture, Planning and Surveying, \\ Universiti Teknologi MARA Shah Alam, Malaysia \\ ${ }^{2}$ Faculty of Health Sciences, Universiti Teknologi MARA Puncak Alam, \\ Malaysia \\ ${ }^{3}$ School of Engineering, Universitat Autonoma de Barcelona, Spain
}

\begin{abstract}
Environmental impacts of cities are a growing concern because of the expanding population, growing demand of natural resources and production of pollutants to the environment. The urban metabolism concept stands on the basic ground that all the movement or flow of materials within an urban system can be accounted systematically. The Economic Input-Output analysis method is applied to the city of Barcelona, Spain as a system boundary to estimate the materials and energy resources required for and the environmental emissions resulting from activities in the economy. Economic input-output analysis is used as an approach to analyze a town metabolism with a demand-based approach. Many inputs and outputs ranging from residential, transportation, consumptions and services can be looked upon in the urban system. Some of the resulting impact of a city are not always immediate and direct, therefore only a complete examination of the urban system could observe those resulting impacts. Through urban metabolism approach, decision are hoped to be made in a more deliberate and systematic way. Limitation to the practice of urban metabolism via economic input-output analysis such as lacking of local and regional data is also addressed.

Keywords: urban metabolism, economic input-output analysis, greenhouse gases emission intensity, Barcelona.
\end{abstract}




\section{Introduction}

The concept of urban metabolism was traced back to the comparison made between an organism and a city by Abel Wolman in 1965. Metabolism converts the fuel in the food we eat into energy needed for everything we do from cellular reactions to physical activities to mental capabilities. Cities, like living organisms, require energy and resources such as fuel, air, water or food as the inputs to sustain their livability. These 'metabolic inputs' are processed and ultimately discharged back to the environment as wastes and emissions, fig. 1 . Hence, the basic rationale behind the urban metabolism concept is that the relationship between the environment and an urban system can be described by systematically recording all flows to and from the environment in physical terms [1]. For the purpose of putting a boundary to the system, a study usually aims to include three major inputs and outputs; energy, waste and water which are significant components of the environment.

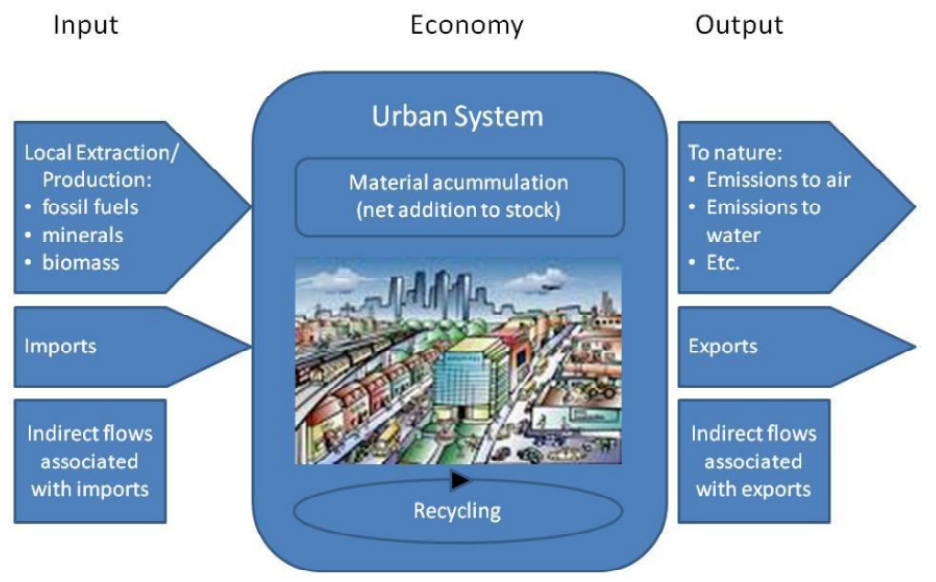

(Source: Minx et al. [1])

Figure 1: Physical exchanges between the urban system and the environment.

One of the approaches that can be used to determine urban metabolism is by using the national or regional economic input-output table. National and regional economic input output data vary according to comprehensiveness of economic data collection and the extensiveness of the data. Some economic input-output data are accompanied with export and import data, simplified economic view and value added services including conversion and regularly used matrices. For European countries, economic input-output data can be retrieved from OECD database. The data are free, simple and accessible by countries allowing potential for broad comparisons. However, lack of supporting data and aggregation to a certain number of economic sectors was seen to be the drawbacks. 
From the basic economic input-output table, a more extensive methodology has been developed. A methodology called the Economic Input-Output Life Cycle Assessment (EIO-LCA) method estimates the materials and energy resources required for, and the environmental emissions resulting from activities in the economy. This method is made available for free via an online tool which could evaluate a product, an industry or service as well as its supply chain. The output could provide an insight on the various impacts along the manufacturing and production line [2].

Economic input-output analysis for the city of Barcelona is conducted to measure the environmental impact in the term of the Global Warming Potential (GWP). In this study, economic inputs are used to determine environmental impacts which could be very practical in identifying the highest contribution to environmental impacts and allowing easier control measures to be directed to. Limitation to the practice of urban metabolism such as lacking of local and regional data is also addressed. Suggestions on a combination of few methods to compare the outcome and references with previous studies conducted on other cities are also detailed out. Although not all urban planning policy questions can be determined via quantitative indicators, reasonably suited tracking and monitoring indicator could really make environmental assessment straightforward and more transparent.

\section{Urban metabolism of Barcelona}

This study applies the identical method to the urban metabolism study applied by the city of Aveiro, Portugal and Marseilles, France [3, 4]. The study would like to provide a simplified overview of the environmental impacts imposed by the city of Barcelona. It is important to note that two previous studies have used the national economic input-output table (Portugal and France) but this study in particular has utilized the regional economic input-output data of Catalonia. Barcelona is the capital of the region Catalonia and is the most populous city in the region. It is the second largest city in Spain after Madrid and the largest metropolis by the Mediterranean Sea. The population of Barcelona is about 1.6 million people [5]. Barcelona has strong influence in tourism, economic, trade fair, sports culture, education, entertainment, fashion, and the arts which all contribute to its status as one of the world's major global cities.

\subsection{Input-output framework of Catalonia}

The Economic Input-Output Framework is a macroeconomic information system that helps improve knowledge of the Catalan economy, as it accurately and congruently explains the economic relations regarding the main operations (production, intermediate consumption, final consumption, investment, exports, imports, etc), by activity branches and products. In the framework of official statistics on Catalonia, the consolidation process of the input-output project is shown by means of two tables for Catalonia, the Input-Output Tables 2001 (TIOC-2001) and the update of the same using the TIOC-2005. 
To update the scheme of sectorial interrelations in these statistics and to ensure their continuity, the Input-Output Framework 2011 project has been initiated, which is currently in the phase of development. Since the 2011 Catalonia Input Output framework is still under development, two sources of Input Output table can be utilized which are from the year 2001 and year 2005. There are two types of tables provided; 65 branches/economic activities and 14 branches/economic activities for both years.

\subsection{The methodology}

Firstly, the monetary fluxes within the economic sectors were obtained. The Catalonia economic Input Output table (data for the year 2005) is provided by the Statistical Institute of Catalonia. It is composed of 14 economic sectors, as shown in table 1 . For this study, the 14 economic sectors Input Output data is used to narrow down the economic sectors due to limitation of data on Catalonia greenhouse gases emission by economic sectors. These 14 economic sectors comprise of almost $96 \%$ of Catalan economy with the value of 458 Million Euro (M€).

Table 1: Classification table of categories for Input-Output Analysis.

\begin{tabular}{|c|c|c|}
\hline \multirow{14}{*}{ 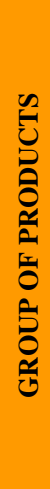 } & A, B & Products of agriculture, livestock, hunting, forestry and fishing \\
\hline & C & Products extractive industries \\
\hline & D & Manufactured products \\
\hline & $\mathbf{E}$ & Electricity, gas and water \\
\hline & $\mathbf{F}$ & Construction work \\
\hline & G & Trade services \\
\hline & $\mathbf{H}$ & Hotel service \\
\hline & I & Transport and communications \\
\hline & $\mathbf{J}$ & Financial intermediation services \\
\hline & $\mathbf{K}$ & Real estate and business services \\
\hline & $\mathbf{L}$ & Administration \\
\hline & M & Education services \\
\hline & $\mathbf{N}$ & Health services and social services \\
\hline & $\mathbf{O}, \mathbf{P}$ & Other social services \\
\hline
\end{tabular}

The basic in understanding economic input-output table to see the product branches by lines and columns. The Input Output table shows the amount of money paid for each economic sector (lines) to manufacture the products of the other sectors (columns). The most significant part of the Input Output table is to derive the "inverse Leontief" matrix or the matrix $(\mathrm{I}-\mathrm{A})^{-1}$. This table can be generated by a spreadsheet software function or in some database; it can be obtained online or sometimes provided together with the raw Input Output data. Part of the "inverse Leontief" matrix for Catalonia is presented below in table 2. 
Table 2: $\quad$ Part of the Catalonia “inverse Leontief” table.

\begin{tabular}{|c|c|c|c|c|c|c|}
\hline & & \multicolumn{5}{|c|}{ Branch of products } \\
\hline & & 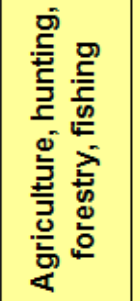 & 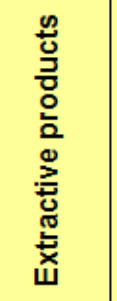 & 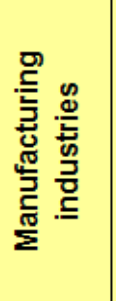 & 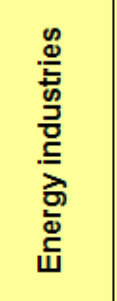 & 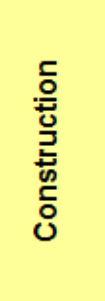 \\
\hline & Products & 01 & 02 & 03 & 04 & 05 \\
\hline 01 & $\begin{array}{l}\text { Products of agriculture, } \\
\text { hunting, forestry, } \\
\text { fishing }\end{array}$ & 1.0497 & 0.0023 & 0.0216 & 0.0014 & 0.0026 \\
\hline 02 & $\begin{array}{l}\text { Products of extractive } \\
\text { industries }\end{array}$ & 0.0013 & 1.0081 & 0.0032 & 0.0020 & 0.0041 \\
\hline 03 & $\begin{array}{l}\text { Manufacturing } \\
\text { products }\end{array}$ & 0.2809 & 0.1272 & 1.2040 & 0.0760 & 0.1411 \\
\hline 04 & Electricity, gas \& water & 0.0291 & 0.0221 & 0.0172 & 1.1398 & 0.0055 \\
\hline 05 & Construction work & 0.0245 & 0.0293 & 0.0087 & 0.0116 & 1.4591 \\
\hline
\end{tabular}

\subsection{Barcelona individual consumption}

The best characteristic of this concept is the versatility in the use and modification of the inverse matrix. If the "inverse Leontief" matrix is multiplied by the final consumption vector $(\mathrm{Y})$, the resulting vector is the gross output $(\mathrm{X})$. "Inverse Leontief" matrix by the final consumption (household consumption) of different products or economic sector can be multiplied to find the gross output needed to supply this regional (Catalonia) demand. The consumption vector (y) could be for a region, a city, a household or an individual consumption. In this study, the individual consumption was considered. Table 3 lists out Barcelona's individual consumption via economic sectors. Population in Catalonia in 2005 is considered to be 6.9 million inhabitants.

\subsection{Greenhouse gases emission intensity}

With the vector of average consumption per capita for Barcelona in 2005, the gross output of all economic sectors needed to attend this demand can be calculated. Having this vector of gross output, it is only needed to multiply it by the average environmental impact factors for each economic sector. These factors were calculated using information of regional greenhouse gases emissions. Conversion from kilotonnes equivalent $\mathrm{CO}_{2}$ /year and Million Euros to kilogram equivalent $\mathrm{CO}_{2} / €$ is conducted appropriately. 
Table 3: Barcelona’s individual consumption.

\begin{tabular}{|l|c|}
\hline Type of economic sector & $\begin{array}{c}\text { Consumption } \\
\text { (€/capita/year) }\end{array}$ \\
\hline Products of agriculture, livestock, hunting, forestry and fishing & 284 \\
\hline Products of extractive industries & 2 \\
\hline Manufactured products & 3130 \\
\hline Electricity, gas and water & 267 \\
\hline Construction work & 121 \\
\hline Trade services & 2229 \\
\hline Hotel service & 2584 \\
\hline Transport and communications & 824 \\
\hline Financial intermediation services & 639 \\
\hline Real estate and business services & 2037 \\
\hline Education services & 305 \\
\hline Health services and social services & 445 \\
\hline Other social services & 968 \\
\hline
\end{tabular}

Table 4: GHG emissions intensity (in kg eq.CO2/€) for each economic sector.

\begin{tabular}{|l|c|c|c|}
\hline \multicolumn{1}{|c|}{ Type of economic sector } & $\begin{array}{c}\text { GHG emission } \\
\text { (kt eq. } \mathbf{C O}_{2} \text { /year) } \\
\text { for 2005 }\end{array}$ & $\begin{array}{c}\text { Gross output } \\
\text { (M€) }\end{array}$ & $\begin{array}{c}\text { GHG emissions } \\
\text { intensity } \\
\text { (kg eq. } \mathbf{C O}_{2} / \mathbf{\epsilon}^{\text {) }}\end{array}$ \\
\hline $\begin{array}{l}\text { Products of agriculture, } \\
\text { livestock, hunting, forestry and } \\
\text { fishing }\end{array}$ & 4360 & 8265 & 0,5275 \\
\hline $\begin{array}{l}\text { Products of extractive } \\
\text { industries }\end{array}$ & 4506 & 3694 & 1,2200 \\
\hline Manufactured products & 15002 & 103421 & 0,1451 \\
\hline Electricity, gas and water & 9429 & 7369 & 1,2796 \\
\hline Construction work & 13714 & 15805 & 0,8677 \\
\hline Transport and communications & 14736 & 23134 & 0,6370 \\
\hline $\begin{array}{l}\text { Health services and social } \\
\text { services }\end{array}$ & 2801 & 11887 & 0,2356 \\
\hline $\begin{array}{l}\text { Real estate and business } \\
\text { services }\end{array}$ & 13714 & 43387 & 0,3161 \\
\hline Education & 2801 & 7025 & 0,3987 \\
\hline Other social services & 2801 & 11828 & 0,2368 \\
\hline
\end{tabular}

The Greenhouse Gases Emissions for Catalonia Inventory is also obtained from Statistical Institute of Catalonia [6]. It appears that for this regional greenhouse gases emission inventory, some economic sectors are lacking of data. The inventory only has seven general categories with limited economic activities namely process energy, industrial process, agriculture and treatment of waste. Therefore, only data that are available and significant are included in this study. Designation of greenhouse gases emission is based on assumption and 
estimation. The economic sectors in input-output table are matched with the economic sectors from the greenhouse gases inventory. Some economic sectors are self explanatory. Assumptions are made to economic sectors lacking the greenhouse gases emissions data. The intensity of economic sectors with lack of data in terms of gross output or greenhouse gases emissions is considered as the same with similar activities (such as for education and other social services).

The results were factors of greenhouse gases (GHG) emissions intensity (kg eq. $\left.\mathrm{CO}_{2} / €\right)$ for the economic sectors and are presented in Table 4. Greenhouse gases emission intensity is required to determine the Global Warming Potential (GWP) by economic sectors and also total greenhouse gases emission for a region or a city.

\section{Impact assessment}

The economic activities linked with their demand are shown in Figure 2. The local population is considered to be average Catalonian people.

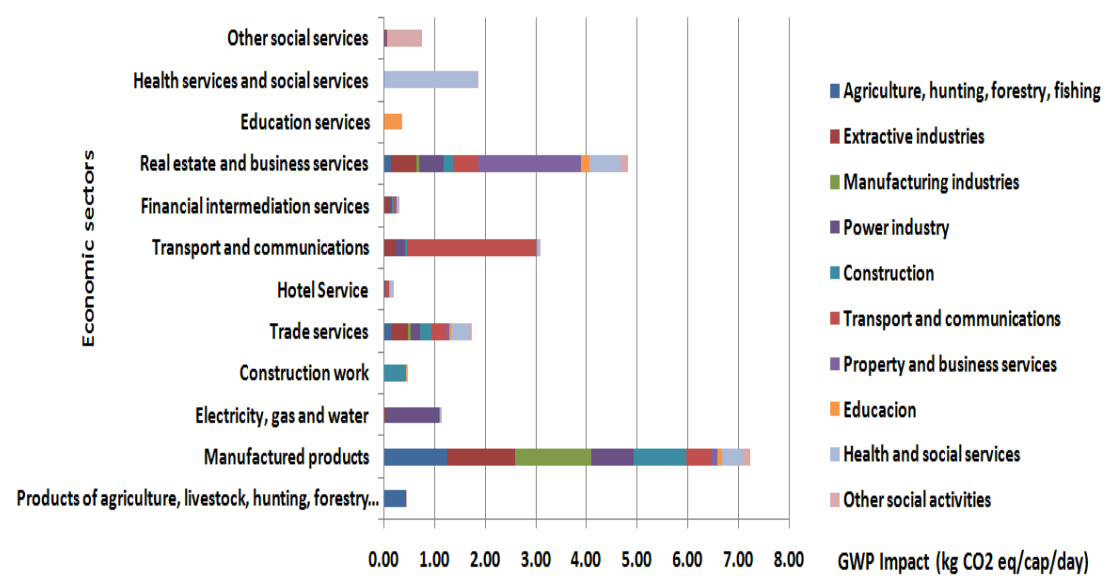

Figure 2: $\quad$ Economic activities in terms of $\mathrm{CO}_{2}$ emission.

From the analysis, it is shown that the demand for manufactured products creates the highest greenhouse gases emissions in its whole supply chain (7.24 $\mathrm{CO}_{2}$ eq./cap/day) followed by the real estate and business services with 4.83 $\mathrm{CO}_{2} \mathrm{eq} . / \mathrm{cap} /$ day. The third highest greenhouse gases emitter is from the transport and communications sector with $3.11 \quad \mathrm{CO}_{2} \mathrm{eq} . /$ cap/day). For manufactured products sector, the highest contributor emission is directly emitted by its own sector. Among the three cities compared cities, the Barcelona manufactured product sector created the highest emission. The reasonable explanation could be the aggregation and definition of the sector 'manufactured products' which could enlist heavy manufacturing industries (such as steel) to light industry (such as household goods). The same case is also apparent for the transport and communication where the highest contributor is by its own sector. It is also 
significant to say that for all three highest sectors, the contributors are within the economy themselves. The demand for hotel service, education and financial intermediation created among the lowest GHG emissions with 0.20, 0.30 and $0.46 \mathrm{CO}_{2}$ eq./cap/day respectively, as seen in table 5 .

Table 5: $\quad$ Details of different emissions for each sector.

\begin{tabular}{|c|c|c|c|c|c|c|c|c|c|c|c|}
\hline Sector Column & 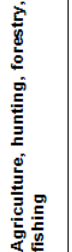 & 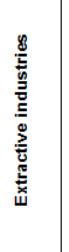 & 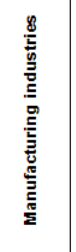 & 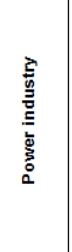 & 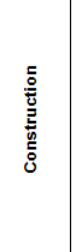 & 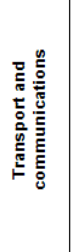 & 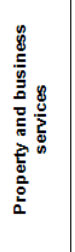 & 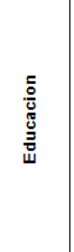 & 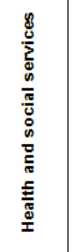 & 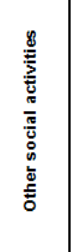 & $\begin{array}{l}\bar{\Xi} \\
\stackrel{\circ}{\circ}\end{array}$ \\
\hline & 0,5275 & 1,22 & 0,1451 & 1,2796 & 0,8677 & 0,8677 & 0,3161 & 0,3987 & 1,385 & 0,2368 & \\
\hline \multicolumn{12}{|l|}{ Sector Line } \\
\hline $\begin{array}{l}\text { Products of agriculture, livestock, } \\
\text { hunting, forestry and fishing }\end{array}$ & 0,4309 & 0,0022 & 0,0024 & 0,0014 & 0,0017 & 0,0010 & 0,0002 & 0,0004 & 0,0031 & 0,0004 & 0,44 \\
\hline Manufactured products & 1,2707 & 1,3311 & 1,4981 & 0,8340 & 1,0498 & 0,4880 & 0,1103 & 0,1082 & 0,4059 & 0,1406 & 7,24 \\
\hline Electricity, gas and water & 0,0112 & 0,0198 & 0,0018 & 1,0687 & 0,0035 & 0,0108 & 0,0016 & 0,0037 & 0,0132 & 0,0033 & 1,14 \\
\hline Construction work & 0,0043 & 0,0118 & 0,0004 & 0,0049 & 0,4189 & 0,0059 & 0,0058 & 0,0027 & 0,0061 & 0,0019 & 0,46 \\
\hline Trade services & 0,1579 & 0,3297 & 0,0453 & 0,1891 & 0,2312 & 0,2941 & 0,0479 & 0,0386 & 0,3580 & 0,0611 & 1,75 \\
\hline Hotel Service & 0,0030 & 0,0207 & 0,0017 & 0,0140 & 0,0055 & 0,0595 & 0,0035 & 0,0259 & 0,0574 & 0,0038 & 0,20 \\
\hline Transport and communications & 0,0254 & 0,2107 & 0,0115 & 0,1707 & 0,0437 & 2,5288 & 0,0260 & 0,0200 & 0,0523 & 0,0170 & 3,11 \\
\hline Financial intermediation services & 0,0164 & 0,1126 & 0,0043 & 0,0405 & 0,0286 & 0,0308 & 0,0248 & 0,0068 & 0,0294 & 0,0066 & 0,30 \\
\hline Real estate and business services & 0,1562 & 0,4862 & 0,0568 & 0,4837 & 0,1949 & 0,4961 & 2,0203 & 0,1720 & 0,6164 & 0,1494 & 4,83 \\
\hline \begin{tabular}{|l|} 
Education services \\
\end{tabular} & 0,0003 & 0,0008 & 0,0002 & 0,0054 & 0,0009 & 0,0018 & 0,0006 & 0,3463 & 0,0020 & 0,0003 & 0,36 \\
\hline Health services and social services & 0,0024 & 0,0006 & 0,0002 & 0,0040 & 0,0006 & 0,0005 & 0,0001 & 0,0000 & 1,8423 & 0,0002 & 1,85 \\
\hline \begin{tabular}{|l|} 
Other social services \\
\end{tabular} & 0,0059 & 0,0149 & 0,0019 & 0,0275 & 0,0092 & 0,0128 & 0,0069 & 0,0037 & 0,0141 & 0,6563 & 0,75 \\
\hline Total & 2,08 & 2,55 & 1,62 & 2,84 & 1,99 & 3,93 & 2,25 & 0,73 & 3,40 & 1,04 & \\
\hline
\end{tabular}

The total emissions for Barcelona amounted to $24.44 \mathrm{~kg} \mathrm{CO}$ eq./cap/day. This result is almost similar to the urban metabolism conducted for Aveiro (25.8 kg $\mathrm{CO}_{2}$ eq./cap/day). The population of Aveiro is about 50,000 people and population of Barcelona is almost 7 million people (which is $67 \%$ of the population of Catalonia). One might question the similarity in the total emissions between Aveiro and Barcelona but the two cities are completely different in terms of population. The acceptable justification could be the different emissions intensity where Barcelona has higher emission density; meaning that Aveiro produces more greenhouse gases per capita per day. In comparison with Marseilles, the total emission for the city of Marseilles is very low which is almost half of Barcelona's total emissions with $13.74 \mathrm{~kg} \mathrm{CO}$ eq./cap/day. However, this comparison is based on an average Catalonia people. For further analysis, taking into account economical specificity of Barcelona could be favourable. In a sense, if we were to compare in terms of population, the Global Warming Potential of Barcelona is much lower. A study on Global Warming Potential among several cities also arrived with even smaller emission for Barcelona with $11.5 \mathrm{~kg} \mathrm{CO} 2 \mathrm{eq} . / \mathrm{cap} /$ day [7].

One of the main reasons that could contribute to the immense different for the same city or location is the source of data and consistency in the methodology of obtaining the Greenhouse Gases emissions [8]. Also, it is worth noting that the previous study by Kennedy et al. [7] applied the Global Warming Potential, expressed in carbon dioxide equivalents, but determined for seven components 
of urban inventories: electricity, heating and industrial fuels, industrial processes, ground transportation, aviation, marine, and waste. Therefore, it can be seen that for this particular study, many of the economic sectors were not included and may just be the sensible explanation to different finding.

\section{Urban metabolism comparisons among Barcelona, Marseilles and Aveiro}

Methodologically, it is feasible to compare this study with the study conducted in Aveiro, Portugal and Marseilles, France. However, it is important to note that there are few differences in the conduct of the study. The main difference in terms of the source of data, that could be highlighted in comparison with Aveiro and Marseilles study are:

a) The source of IO data - National Input Output table were used in Aveiro and Marseille while Barcelona used regional data.

b) The compilation of economic Input Output data varies according to the economic sector classification and what is defined by the economic sectors.

For example, in food and agricultural sector of Marseilles and Aveiro, tobacco products are included but not for Barcelona economic data. For the construction sector, Barcelona and Marseilles value consist of purely construction work while for Aveiro, real estate (including house renting) is included under construction. Private consumption of the three cities is presented in table 6. Consistencies in certain economic sectors can be seen between the cities especially in Health and Social Work sector, Education, Transportation and other social services. In certain economic sectors such as the hotel services and construction, broad difference can be observed which is then stressed upon that the "definition" of the economic sector may have generate such result.

Table 6: $\quad$ Private consumption for Barcelona, Marseilles and Aveiro in Euro $(€)$.

\begin{tabular}{|l|l|l|l|}
\hline Economic sector & Barcelona & Marseilles & Aveiro \\
\hline Health and social work & 445 & 586 & 201 \\
\hline Education & 305 & 141 & 128 \\
\hline Construction & 121 & 149 & 1886 \\
\hline Transportation & $824 *$ & 501 & 704 \\
\hline Hotel services & 2584 & 877 & 920 \\
\hline Agriculture products; food & 284 & 1261 & 1510 \\
\hline Electricity, gas and water & 267 & - & 454 \\
\hline Other social services & 968 & 675 & 551 \\
\hline
\end{tabular}

*transport and communication

Aggregations of values are made to Aveiro and Marseilles greenhouse gases emission intensity to better compare the two cities in terms of economic sectors. 
Overall, Barcelona has higher greenhouse gases emission intensity in all economic sectors except in products of extractive industries.

The present accounting methods of greenhouse gases emissions can be roughly categorized into production-based and consumption-based accounting approaches [9]. Production-based approaches are always exemplified in nationalscale inventories and track mainly the direct greenhouse gases emissions across all production sectors and the residential sector within the political or geographical boundary while consumption-based accounting is surrogated by local household expenditure linked with the consumption level of the city dwellers. These two approaches in greenhouse gases accounting may also result in different economic-environment output. Geographical and economic boundary also contributes to the final accounting.

This study has tried to utilize more regional data to obtain the more accurate view of the urban metabolism. However, the lack of data both in the economic sectors and greenhouse gases emissions may contribute to uncertainties and incompatibility for comparison with other cities. It can be seen that a more disaggregated and complete economic input output table would improve the final outcome. Among the economic sectors that could be added in, could be the wastewater, solid waste and recycling sectors. Downscaling of data can be avoided if more city scale information on private households can be obtained and utilized.

\section{Conclusion}

The urban metabolism together with the life cycle approach within the design and planning level is able to recognise if the decision made in the early stages of planning will result in the following urban stages. The "behaviour" of a city can be foreseen and necessary mitigating and control measures especially on the resource consumption can be taken up. Various approaches on assessing the urban environment should be applied and tested by the research community. Introduction and revisiting an existing or a new concept can be taken up for case studies so that the merits of the approach can be discussed and debated and the applicability can be investigated. Policies on urban planning should incorporate environment and health aspects. The research guided policies should encouraged and necessary changes to existing policies should be welcomed for the betterment of the city dwellers and the environment. Some of the resulting impacts of a city are not always immediate and direct; therefore only a complete examination of the metabolism of the urban system could observe those resulting impacts. Through a life cycle and economic approach, planning decisions are hoped to be made in a more deliberate and systematic way.

\section{Acknowledgements}

The authors would like thank the European Commission - Man, Health, Environment and Biodiversity in Asia (MAHEVA) programme for providing the opportunity for us to work with the wonderful researchers of SosteniPra and 
Inedit in Universitat Autonoma de Barcelona. Special thanks also go to Dr Xavier Gabarell of the Chemical Engineering Department, Universitat Autonoma de Barcelona, Spain for his continuous support during the MAHEVA mobility. The authors would also like to thank Dr Gara Villalba, Dr Abel Chavez, Mr Álvaro González Roof and Mr Nicolas Mat for their guidance and expertise.

\section{References}

[1] Minx, J., Creutzig, F. Medinger, V. Ziegler, T., Owen, A. and Baiocchi, G. Developing A Pragmatic Approach To Assess Urban Metabolism In Europe: A Report to the European Environment Agency. Stockholm Environment Institute, 2010.

[2] Carnegie Mellon University Green Design Institute. Economic Input-Output Life Cycle Assessment (EIO-LCA], Online. http://www.eiolca.net/

[3] Lemos, D. S., Urban Metabolism of Aveiro: LCA of the City Demands and Water Cycle. University of Aveiro, Portugal, 2011.

[4] Mat, N. and Gonzalez-Roof, A., Urban metabolism of Marseille Provence Metropole: An Overview of Material and Energy Flows on Marseilles through different methodologies of mass and financial balance and environmental impact. EcoTech Sudoe, n.p., 2012.

[5] Statistical Institute of Catalonia, Input-Output Tables for Catalonia 2005, Online. http://www.idescat.cat/en/economia/tioc/\#a1

[6] Statistical Institute of Catalonia, Catalonia Green House Gases Emissions. Online.http://www20.gencat.cat/portal/site/canviclimatic/menuitem.c4833b4 94d44967f9b85ea75b0c0e1a0/?vgnextoid=87b2da5a182fb210VgnVCM200 0009b0c1e0aRCRD\&vgnextchannel=87b2da5a182fb210VgnVCM2000009 b0c1e0aRCRD\&vgnextfmt=default

[7] Kennedy, C., Steinberger, J., Gasson, B., Hansen, Y., Hillman, T., Havranek M., Pataki D., Phdungsilp A., Ramaswami A. and Villalba Mendez, G., Greenhouse Gas Emissions from Global Cities. Environmental Science and Technology, 43(19): 7297-7302, 2009.

[8] Ramaswami A., Chavez A., Ewing-Thiel J. and Reeve, K.E., Two approaches to greenhouse gas emissions foot-printing at the city scale. Environmental Science and Technology 45: 4205-4206, 2011.

[9] Lin, T., Yu, Y., Bai, X., Feng, L. and Wang, J., Greenhouse Gas Emissions Accounting of Urban Residential Consumption: A Household Survey Based Approach. PLoS ONE 8(2): e55642, 2013. 